\title{
Espírito rixoso: para uma reinterpretação das Memórias de um sargento de milícias
}

Edu Teruki Otsuka**

Resumo

Este artigo procura sugerir uma releitura das Memórias de um sargento de milícias, de Manuel Antônio de Almeida, dando continuidade à interpretação apresentada por Antonio Candido no conhecido ensaio "Dialética da malandragem". Pretende-se aprofundar a investigação dos fundamentos sociais da forma das Memórias por meio do exame de uma dimensão da obra que até agora não foi explorada: o núcleo de violência que, no plano das relações entre as personagens, se manifesta sob a feição de rixas e vinganças. Busca-se indicar que a estrutura de rixas determina a organização formal do romance, sendo, ao mesmo tempo, resultante de práticas sociais mais amplas, próprias ao país periférico de economia escravista.

\section{Palavras-chave}

Manuel Antônio de Almeida, forma literária, sociedade brasileira, estrutura de rixas, malandragem.

* este artigo procura apresentar as linhas gerais da tese de doutorado OTSUKA, Edu Teruki. Era no tempo do rei: a dimensão sombria da malandragem e a atualidade das Memórias de um sargento de milícias. 2005. 170 f. Tese (Doutorado em Literatura Brasileira) - Faculdade de Filosofia e Ciências Humanas, Universidade de São Paulo, São Paulo, 2005. Elaborada sob orientação do Prof. José Antonio Pasta Jr.

*** professor do Departamento de Teoria Literária e Literatura Comparada da FFLCH-USP e autor de Marcas da catástrofe: experiência urbana e indústria cultural em Rubem Fonseca, João Gilberto Noll e Chico Buarque. São Paulo: Nankin Editorial, 2001. 
revista do ieb n 44 p. 105-124 fev 2007

\section{A quarrelsome spirit: an interpretation of Memórias de um sargento de milícias}

Edu Teruki Otsuka

Abstract

This paper aims to suggest a new reading of Manuel Antônio de Almeida's novel, Memórias de um sargento de milícias (Memoirs of a militia sergeant), by developing Antonio Candido's interpretation present in his essay "Dialética da malandragem". I intend to take a step further the investigation of the social foundations of the form of Memórias through the study of a dimension of the novel that has been left hitherto unexplored: the core of violence which appears, at the level of the characters' relationships, under the guise of quarrels, scuffles and vengeances. As I try to suggest, the structure of quarrels and scuffles determines the formal organization of Almeida's novel, and it is at the same time a result of wider social practices peculiar to a slave-based peripheral country.

\section{Keywords}

Manuel Antônio de Almeida, literary form, Brazilian society, structure of quarrels and scuffles, roguery. 
Em 1970, Antonio Candido publicou o ensaio "Dialética da malandragem" - um dos poucos verdadeiros eventos da crítica literária brasileira - e alterou definitivamente o modo de ler as $\mathrm{Me}$ mórias de um sargento de milícias, de Manuel Antônio de Almeida ${ }^{1}$. Ao caracterizar a malandragem dos personagens como um comportamento regido pela "dialética de ordem e desordem" e identificar essa dialética como princípio formal do romance, Candido fez uma descoberta crítica avassaladora, que superou os estudos anteriores sobre as Memórias e definiu os termos em que a obra passaria a ser entendida. Sua interpretação realizou o feito de revelar no romance uma camada de significação até então oculta, demonstrando que a lógica da organização narrativa apreende um dinamismo histórico-social próprio ao Brasil da primeira metade do século XIX. De quebra, e a partir da análise estética, Candido também nomeou e conceitualizou essa dinâmica vigente nas práticas efetivas da sociedade brasileira, escravista e dividida em classes. Hoje é possível dizer que sua penetrante explicação do arranjo formal das Memórias passou a fazer parte do sentido da obra.

Mas talvez se possa dizer também, generalizando um pouco, que a visão corrente sobre as Memórias, rotinizada depois da "Dialética da malandragem", baseia-se em apenas um (a meu ver, o menos revelador) dos movimentos interpretativos do ensaio de Candido. Com efeito, tal visão parece destacar no romance a representação da malandragem entendida somente como um traço cultural do brasileiro em geral, e não tanto a figuração da malandragem enquanto comportamento historicamente enraizado no quadro específico das relações entre as classes na sociedade brasileira oitocentista - em que no entanto está, pelo menos a meu ver, a contribuição decisiva do ensaio de Candido para a crítica literária materialista.

Entendida exclusivamente como traço cultural brasileiro, a malandragem tende a ser desvinculada do quadro determinado da organização econômico-social. Desse modo, contudo, a relação

1 Publicado na "Pacotilha" (Correio Mercantil) em 1852-3, o romance de Manuel Antônio de Almeida foi editado em dois tomos em 1854-5. A edição usada para citações neste artigo é ALMEIDA, Manuel Antonio de. Memórias de um sargento de milicias. Fixação de texto Mamede Mustafa Jarouche. São Paulo: Ateliê, 2000. 0 estudo de Antonio Candido, Dialética da malandragem, publicado originalmente em: CANDIDO, Antonio. Dialética da malandragem. Revista do Instituto de Estudos Brasileiros, São Paulo, n. 8, p. 67-89, 1970 encontrase agora em CANDIDO, Antonio. 0 discurso e a cidade. São Paulo: Duas Cidades, 1993. p. 19-54. 0 ensaio foi comentado em detalhe por SCHWARZ, R. Pressupostos, salvo engano, da Dialética da malandragem. In: Que horas são? São Paulo: Companhia das Letras, 1989. p. 129-155; ver também SCHWARZ, R. Outra Capitu. In: . Duas Meninas. São Paulo: Companhia das Letras, 1997. p. 132-5; e ARANTES, Paulo E. Sentimento da dialética na experiência intelectual brasileira. Rio de Janeiro: Paz e Terra, 1992. 
entre as Memórias e a sociedade brasileira, tal como apresentada por Candido, fica atenuada (ou talvez mesmo neutralizada). Isso porque a relação entre a obra e a sociedade passa a restringir-se à simples correspondência entre a malandragem literariamente figurada no romance e o comportamento malandro existente na realidade, sem que, no entanto, a própria malandragem real seja entendida em seus fundamentos histórico-sociais (apenas se constata a sua existência no plano da realidade, como um fato auto-evidente que parece não exigir outra explicação para além do impalpável ethos nacional). Nesse movimento, perde-se uma parte importante da interpretação de Antonio Candido, pois as clivagens internas à sociedade brasileira, com suas desigualdades brutais, que explicam historicamente o predomínio da "dialética de ordem e desordem" tanto na ficção quanto na realidade, bem como os modos de reprodução das fraturas sociais, que explicam a persistência da malandragem, acabam sendo deixados na sombra.

Entretanto, e sem deixar de sublinhar a força reveladora de "Dialética da malandragem", talvez seja preciso reconhecer também que o próprio ensaio de Antonio Candido apresenta um movimento em que a visada histórica e materialista cede lugar a uma espécie de generalização de cunho culturalista (esse problema foi assinalado por Roberto Schwarz). Como é sabido, na seção final do ensaio Candido conduz o argumento para a indagação acerca do rumo histórico da sociedade, elevando a sociabilidade malandra ao plano das "grandes opções da história contemporânea"2, o que, sem dúvida, é uma ousadia crítica admirável em sua intenção, pois as formas espontâneas de sociabilidade engendradas no "mundo sem culpa" brasileiro deixam de ser vistas como inferioridade, assim como o endurecimento moral das sociedades capitalistas avançadas deixa de ser visto como superioridade inconteste. Mas, nesse movimento, Candido acaba abandonando a especificação histórica efetuada por ele mesmo no passo anterior e monta um quadro comparativo (com o puritanismo norte-americano) em que a malandragem aparece apenas como um "modo de ser" brasileiro. De acordo com Schwarz, embora Antonio Candido realize um tipo de crítica então inédito no Brasil, lendo a ficção sobre o fundo real e vice-versa, com ênfase no âmbito das formas, o ensaio apresenta também um limite, o qual estaria principalmente na leitura que Candido faz da reali-

2 SCHWARZ, R. Pressupostos, salvo engano, da Dialética da malandragem. In: ______. Que horas são? São Paulo: Companhia das Letras, 1989. p. 151. Para uma análise da última ironia da História quanto às metamorfoses da malandragem no mundo contemporâneo, ver ARANTES, Paulo E. A fratura brasileira do mundo: visões do laboratório brasileiro da mundialização. In: Zero à esquerda. São Paulo: Conrad, 2004. p. 25-77. 
dade histórica (e isso não só porque uma certa "dialética de ordem e desordem" também contribuiu para que se efetivasse a modernização conservadora do pós-1964). Em contrapartida, a leitura da ficção - que, repita-se, abriu perspectivas novas para a crítica materialista, aliás talvez ainda não devidamente assimiladas de maneira ampla em todas as suas implicações - parecia permanecer irretocável. No entanto, não haveria também um limite correlato na própria leitura da configuração estética das Memórias?

Para avançar na especificação do princípio formal das Memórias de um sargento de milícias sem perder de vista as suas determinações histórico-sociais, talvez seja preciso rever os termos em que a malandragem é elaborada na obra de Manuel Antônio de Almeida. Com a especificação desses termos, seria possível, talvez, dar contornos mais nítidos ao modo como o princípio estruturador do romance apreende a lógica profunda da organização social, objetivando-a na forma literária. Para isso, cumpre investigar elementos da configuração das Memórias que não foram (ou foram apenas em parte) considerados por Antonio Candido.

Se acompanharmos o andamento da ação, mesmo em sua camada mais superficial, observaremos que o modo como os personagens se relacionam obedece a uma lógica peculiar. 0 conflito central do enredo, entre Leonardo e o major Vidigal, certamente envolve infrações à lei e à ordem estabelecida (de parte a parte); entretanto, a própria flutuação entre o lícito e o ilícito está atrelada ao problema da desavença pessoal. Na primeira tentativa de prender o herói, Vidigal é enganado pela astúcia do malandro, que, no caminho para a Casa da Guarda, consegue escapar dos granadeiros e da vigilância do poderoso major. Sentindo-se humilhado com o fato, pois não tolerava ser ofendido em sua vaidade, Vidigal passa a alimentar uma rixa com Leonardo: "tinha-o por seu inimigo irreconciliável enquanto não lhe desse desforra completa" (p. 276). A conseqüência da fuga do malandro é, assim, o desejo de vingança pessoal do major, o qual acaba se sobrepondo à incumbência de manutenção da ordem. De fato, o representante-mor da lei chega mesmo a temer que o herói venha a "emendar-se", isto é, a viver de acordo com os preceitos da legalidade (alcançando um ofício regular, por exemplo), pois isso impediria o major de conseguir sua desforra: "Se ele [Leonardo] se

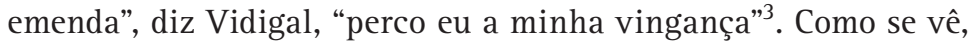
o próprio funcionamento da oscilação entre o lícito e o ilícito está subordinado ao problema da rixa pessoal.

Não é apenas no confronto entre o malandro e o chefe de polícia que se pode notar esse tipo de relação conflituosa baseada

3 ALMEIDA, Manuel Antônio de. Memórias de um sargento de milícias. Fixação de texto Mamede Mustafa Jarouche. São Paulo: Ateliê, 2000. p. 282. Doravante MSM. 
na discórdia entre os personagens. Ao longo do romance, nota-se a recorrência do mesmo comportamento, que se manifesta em graus variados e sob diferentes feições. No início do romance, o barbeiro passa a cuidar de Leonardo e deseja fazer dele um clérigo prestigioso. Observando o fracasso do compadre em suas tentativas de ensinar o menino a rezar, a vizinha mexeriqueira zomba do barbeiro, no que é acompanhada pelos risos de outros vizinhos. 0 compadre reage, trocando injúrias com ela, até ser vingado pelo afilhado, que ridiculariza a vizinha, dando ocasião para que, desta vez, o barbeiro ria-se dela em desforra. Pouco depois, Leonardo volta a aprontar com a vizinha na igreja, que logo se queixa ao mestre de cerimônias; sendo repreendido pelo clérigo, o herói resolve vingar-se dele fazendo-o atrasar-se para o sermão. 0 mestre de cerimônias, por sua vez, indispõe-se contra o capuchinho que passara a fazer o sermão em seu lugar e, por fim, despede Leonardo das funções de ajudante de sacristão. A vizinha, sentindo-se vingada, volta a achincalhar o barbeiro.

Em outro passo, Leonardo-Pataca sente-se traído pela cigana, com quem mantinha uma relação amorosa, porque ela o trocara pelo clérigo. Com o intuito de vingar-se dela, Pataca contrata o valentão Chico-Juca para armar confusão na festa de aniversário da cigana. Esse personagem, Chico-Juca, pode ser visto como a própria personificação da desavença cotidiana: ocupando o "trono da valentia"4 e dando pancada por dinheiro, aproveita-se de sua força física bruta para fazer das rixas pessoais um meio de vida. Em grau diferente de discórdia, o patusco Teotônio mobiliza a zombaria para divertimento de seus pares. Animando uma festa com sua habilidade de fazer caretas, ele aproveita a ocasião para ridicularizar o chefe de polícia, diante do major em pessoa: imita "com muita semelhança a cara comprida e chupada do Vidigal" 5 , provocando o riso estrondoso dos convivas. Previsivelmente, Vidigal não aprecia a brincadeira e fortalece sua intenção de prender Teotônio, agora seu desafeto pessoal ("Não quero", diz o major, "que aquele valdevinos ande tomando impunemente a minha cara para original de caretas" ${ }^{6}$ ). Outro personagem secundário, José Manuel, encarna mais uma faceta da desavença pessoal. Caracterizado como um velhaco cuja característica mais saliente é a maledicência, ele se insinua com suas histórias e sua lábia no ambiente abastado de D. Maria

4 MSM, p. 152.

5 MSM, p. 308.

6 MSM, p. 309. 
e Luisinha e, desse modo, faz sombra a Leonardo, com quem rivaliza na disputa pela sobrinha da ricaça.

Já D. Maria, a única personagem da classe proprietária que cumpre papel relevante no enredo, é apresentada como uma respeitável senhora maníaca por demandas ("as suas demandas eram o alimento da sua vida; acordada pensava nelas, dormindo sonhava com elas; raras vezes conversava em outra coisa"7). Embora o narrador a descreva como uma velha de "bom coração", "devota e amiga dos pobres" , D. Maria não deixa de manifestar também certa inclinação para a disputa pessoal. Sendo "extremosa em suas afeições, como em seus ódios", , ela se vale dos processos judiciais para resolver as desavenças e reafirmar seu poder de proprietária que não admite afrontas: "Se eu fosse parente da rapariga havia de pôr uma demanda ao tal diabo que o havia ensinar..."10, diz D. Maria depois de ouvir o caso da moça do oratório que fugira com o namorado.

Finalmente, em um momento em que mantém uma relação amorosa com Vidinha, Leonardo, então empregado na ucharia real, paquera também a moça do caldo e entra em conflito com o tomalargura, namorado da moça. Movida pelo ciúme, Vidinha, por sua vez, vai tirar satisfação com a moça do caldo e acaba despertando o interesse do toma-largura; enquanto isso, Leonardo é capturado por Vidigal. Pouco depois, o toma-largura passa a relacionar-se com Vidinha e o faz, em parte, para vingar-se do malandro ("Leonardo o havia ofendido; conquistar ainda que fosse uma diminuta parcela do amor da Vidinha seria ao mesmo tempo vingar-se do Leonardo e alcançar o triunfo de um desejo" ${ }^{11}$ ). Na seqüência, o herói, já granadeiro sob as ordens do major, aproveita uma situação casual para vingar-se do toma-largura, que, quando bebia, "dava-lhe para valentão e desordeiro"12. Ao confrontar novamente o rival, Leonardo se encontra na função de soldado; como o toma-largura havia armado briga em uma festa, o herói é incumbido de prendêlo, o que lhe permite triunfar sobre o adversário, mesmo sem concluir a prisão, e ainda que Leonardo não volte a reatar relações com Vidinha, que aliás desaparece do enredo.

7 MSM, p. 166.

8 MSM, p. 166.

9 MSM, p. 220.

10 MSM, p. 214.

11 MSM, p. 291.

12 MSM, p. 297. 
A referência a episódios de teor semelhante poderia ser facilmente ampliada, mas as breves paráfrases apresentadas acima talvez sejam suficientes para notarmos que, além de transitarem livremente entre as esferas da ordem e da desordem, os personagens apresentam, de maneira sistemática, comportamentos fortemente marcados por traços mais ou menos assemelhados, como a maledicência, a zombaria, o achincalhe, a rivalidade e sobretudo a vingança; assim, os relacionamentos interpessoais que predominam no universo social das Memórias configuram uma estrutura peculiar, sendo governados por uma inclinação geral, comum aos personagens, a que se poderia chamar de espirito rixoso. Além disso, uma atitude semelhante se revela no próprio discurso do narrador, que se distingue pela ironia maliciosa com que descreve cenas, acontecimentos e personagens - ironia que atinge tanto os personagens marcadamente antipáticos, como José Manuel ("Se tinha alguma virtude, era a de não enganar pela cara"13), quanto o próprio herói, que levava "uma vida tão regular e tão lícita" ${ }^{\text {. Como }}$ se pode perceber pelos episódios mencionados, a tendência para a discórdia pessoal não é uma simples excentricidade ou idiossincrasia restrita a um ou a outro personagem, mas sim um padrão de comportamento que se manifesta em praticamente todas as relações interpessoais figuradas nas Memórias, bem como na perspectiva do narrador. Nesse sentido, pode-se dizer que o espírito rixoso se generaliza no romance e apresenta caráter estrutural.

Percebe-se também (sobretudo na seqüência que envolve o barbeiro, a vizinha, Leonardo, o mestre de cerimônias e o capuchinho) que a maneira como as vinganças estão encadeadas segue uma lógica específica. As desavenças se multiplicam, gerando outras, que geram outras, contaminando os personagens, como em uma reação em cadeia. Junto a essa disseminação da discórdia, a dinâmica das rixas caracteriza-se pela permutabilidade dos personagens, de tal modo que a derrota em uma disputa leva aquele que foi inicialmente humilhado a buscar vingança, trocando-se as posições em caso de triunfo na nova contenda; mas o personagem agora derrotado se sentirá ofendido em seu amor-próprio e tentará a desforra por sua vez - e com isso reinicia-se o movimento ${ }^{15}$. Instauram-se, assim, ciclos de disputas pessoais que recomeçam

13 MSM, p. 186-7.

14 MSM, p. 276.

15 Em sua lógica, a rixa apresenta certa afinidade com a "luta de morte" teorizada por José Antonio Pasta Jr. Ver PASTA JR, José Antonio. 0 romance de Rosa: temas do Grande Sertão e do Brasil. Novos Estudos CEBRAP, São Paulo, n. 55, p. 61-70, nov. 1999. 
de maneira incessante, sem chegar a termo. Um efeito disso é que o padrão de rixas parece automatizar-se, ou mesmo autonomizarse, como que se reproduzindo indefinidamente por si só ${ }^{16}$.

Além disso, nota-se que as desavenças parecem ser, geralmente, provocadas por motivos fúteis ou banais. Mas, qualquer que seja a motivação mais direta, as rixas mostram-se sempre associadas a um desejo dos personagens de sobrepor a própria pessoa aos outros, para se colocarem em posição de superioridade em relação aos demais, ainda que apenas momentaneamente. Os motivos de contenda apresentados pelo acaso fornecem ocasião aos personagens para que, com a disputa, possam atingir uma supremacia qualquer ${ }^{17}$. Tanto assim que mesmo as disputas amorosas, como o episódio do toma-largura mostra, não dependem somente da paixão pela mulher disputada, mas também do desejo de sobrepujar o rival. Nesse sentido, é significativo que, no último confronto entre Leonardo e o toma-largura, Vidinha deixe de comparecer como objeto último da contenda; no fim, o que importa parece ser menos a conquista da mulher do que a sujeição do adversário, como se a motivação original fosse esquecida, e a rixa se convertesse em sua própria finalidade - daí o efeito de autonomização das rixas.

Desse modo, embora os motivos mais diretos das desavenças possam ser, até certo ponto, considerados banais, talvez não seja o caso de simplesmente descartá-los como meros pretextos que encobrissem uma razão oculta e mais verdadeira. Isso porque os motivos que ocasionam as disputas só podem ser considerados fúteis do ponto de vista da racionalidade moderna, em que os pretextos alegados são meros acessórios que ocultam uma finalidade maior, em relação à qual os motivos casuais parecem insignificantes. No universo social das Memórias, são os próprios motivos banais que funcionam como fins em si mesmos; ou melhor, o desejo de supremacia sobre os outros, que está atrelado às rixas, só se concretiza nas disputas por motivos fúteis, e não tanto em um projeto que se oculta por baixo de pretextos circuns-

16 A idéia de autonomização das rixas foi sugerida por Paulo Arantes, que se reportou à tradição duelista em Jorge Luis Borges (em particular em "El encuentro", de El informe de Brodie), a partir de um estudo em andamento de Grécia Sobera.

17 Como se sabe, a expressão provém de Machado de Assis: em suas brincadeiras de criança, Quincas Borba "escolhia sempre um papel de rei, ministro, general, uma supremacia, qualquer que fosse” (ASSIS, Machado de. Memórias póstumas de Brás Cubas, Rio de Janeiro: Garnier, 1988. p. 52). Para uma análise da questão, ver SCHWARZ, R. Um mestre na periferia do capitalismo. São Paulo: Duas Cidades, 1990. p. 30-31, 63. 
tanciais. Com efeito, as desavenças dos personagens em torno de questões (aparentemente) fúteis ganham importância crucial no enredo, definindo-lhe a movimentação particular, da qual está ausente qualquer finalidade última que norteie o desenvolvimento da história no conjunto.

0 padrão definido pelo espírito rixoso generalizado, que estamos descrevendo, apresenta inúmeras implicações formais. Para ficarmos apenas no nível mais óbvio, note-se que o movimento de vinganças e disputas pessoais, com sua alternância de altos e baixos na posição dos personagens, ajuda a entender a dinâmica da vida de Leonardo, tal como o narrador a caracteriza: "para ele não havia fortuna que não se transformasse em desdita, e desdita de que lhe não resultasse fortuna"18. Essa "lei" que rege a vida do herói é confirmada pelo andamento da linha principal do enredo e, em grande medida, vale também para os episódios secundários. 0 movimento específico da ação do romance, muito marcado por reviravoltas, está intimamente ligado à lógica dos relacionamentos rixosos.

Restritas ao plano circunstancial dos motivos casuais, as pequenas rixas e vinganças que se disseminam nas Memórias destoam da vingança tal como elaborada no romance românticorealista europeu. Em uma obra como $O$ conde de Monte Cristo, por exemplo, a figuração da vingança apresenta um sentido historicamente particular, na medida em que se combina com valores próprios à sociedade capitalista burguesa em desenvolvimento, de acordo com a "nova fase de conquista da posição social pela seleção do talento e da habilidade"19. Assemelhando-se ao projeto racional de um empreendedor, a vingança aparece ali como uma manifestação do individualismo burguês, fundado no princípio de competição do liberalismo econômico. Em outras palavras, o tema pré-burguês da vingança pessoal serve à figuração de um empreendimento racional de caráter propriamente burguês.

Além disso, no romance romântico-realista, o projeto de vingança nutrido pelo protagonista confunde-se com a própria trajetória biográfica, que constitui o eixo em torno do qual o enredo se estrutura. Dizendo de modo esquemático, naquele tipo de romance a linha biográfica que nucleia a narrativa pressupõe a idéia de desenvolvimento do indivíduo, o qual se concebe a si mesmo como livre e autônomo. A ação é impulsionada pela vontade do protagonista de concretizar seu projeto de auto-realização (a as-

18 MSM, p. 299.

19 CANDID0, Antonio. Da vingança. In: Tese e antitese. 2. ed. São

Paulo: Nacional, 1971. p. 13. 
censão social, a conquista amorosa, a aquisição de bens etc.). Com iniciativa e pulso firme, ele busca realizar seu projeto apoiando-se no cálculo racional e, no percurso, acaba entrando em conflito com alguns valores postulados pela mesma sociedade que o conduz à utilização instrumental da racionalidade e das outras pessoas. Como se sabe, essa concepção de indivíduo livre e autônomo é um dos múltiplos resultados da generalização da forma mercadoria ao longo do processo de expansão do capitalismo, em que está alicerçado o estabelecimento da ordem burguesa ${ }^{20}$.

Em contraste, nas Memórias as vinganças não são metódicas ou racionalizadas; assemelham-se antes a revides irrefletidos, que se esgotam na própria situação restrita em que surgiram, embora possam engendrar outras vinganças (igualmente ocasionais). Limitadas pelas motivações imediatas das circunstâncias casuais, as vinganças nas Memórias não têm grandes desdobramentos no horizonte temporal; pelo contrário, o que se observa é a sucessão de pequenas vinganças que se substituem em ciclos incessantemente renovados. À diferença do antagonismo absoluto do romance burguês, encontra-se aqui a multiplicação de disputas por picuinhas.

Essa divergência na magnitude dos conflitos, evidenciada nas figurações da vingança, deve-se aos diferentes pressupostos histórico-sociais de cada forma. A estruturação dominante no romance burguês - com seu desenvolvimento dramático amplo, governado pela busca consciente de uma finalidade última - está enraizada no processo específico da consolidação da ordem burguesa, em que a troca mercantil se erige como o nexo fundamental que molda a sociedade no conjunto. Como veremos mais detalhadamente a seguir, o domínio das rixas vingativas no romance de Manuel Antônio funda-se em um processo que, embora articulado ao outro, destoa dele, pois no Brasil oitocentista a prevalência do escravismo produzia particularidades na organização social, que definem a feição específica da matéria social brasileira.

Nessas condições, a organização geral do enredo das Memórias não poderia seguir a mesma estrutura que norteia o romance burguês. 0 esquema episódico da organização das Memórias, que caracteriza o nível mais ostensivo da forma, corresponde justamente ao domínio dos relacionamentos rixosos no plano da ação, o que imprime ao enredo um ritmo entrecortado de reviravoltas sobre reviravoltas, pautado na seqüência de segmentos narrativos que equivalem às situações restritas da rixa, com interrupções momentâneas e infinitos recomeços. Desse modo, a figuração de uma sociedade em que vigora o espírito rixoso exigia uma

20 Ver SCHWARZ, R. Ao vencedor as batatas. 2. ed. São Paulo: Duas Cidades. 1981. 
organização formal que se distanciava das formas mais avançadas do romance produzidas na época de Manuel Antônio ${ }^{21}$.

Acresce que o próprio movimento de ascensão do herói é impulsionado por modos de relacionamento também particulares. Como observou Mário de Andrade, "Leonardo não é um homem que se faz por si, os outros é que fazem por ele"22. De fato, como o narrador comenta, o jogo de empenhos e cartuchos era a "mola real de todo o movimento social" ${ }^{23}$. Longe de apresentar a trajetória do desenvolvimento de um indivíduo, as Memórias mostram um percurso marcado pela acomodação às circunstâncias e aos reveses da fortuna. 0 resultado é a permanência do personagem em um persistente estado de tutela, que decorre das práticas vigentes no universo figurado no romance, ou seja, as práticas governadas pela lógica do favor, cuja função estrutural na sociedade escravista é confirmada no enredo das Memórias ${ }^{24}$. Representando o funcionamento das relações de favor pelo viés da comicidade, o romance as desqualifica a partir da perspectiva moderna, ao mesmo tempo em que produz o efeito de desqualificar como ideológica a concepção de indivíduo livre e autônomo, que não encontra efetividade na prática.

No entanto, ao lado das relações de favor, o que sobressai no romance de Manuel Antônio é o predomínio das rixas, que

21 A estruturação episódica da narrativa e a presença do personagem astucioso já foram tomados pela crítica, de modo a-histórico, como simples atualização de convenções da tradição literária, em particular da novela picaresca espanhola. Do mesmo modo, a representação caricatural de personagens-tipo, em parte usada por Manuel Antônio, poderia remeter à farsa, assim como o recurso à reviravolta poderia ser associado à tradição burlesca. Contudo, ainda que esses vínculos com a tradição pudessem ser plenamente comprovados, para um ponto de vista histórico interessa investigar o resultado do aproveitamento das convenções tradicionais em sua conjunção com a matéria histórico-social, que lhes redefine a funcionalidade e o sentido. Na nova configuração formal, a eficácia e a significação dos elementos tradicionais ficam subordinadas aos significados histórico-sociais específicos da matéria elaborada na obra, e, dessa perspectiva, o vínculo com a tradição prévia, tomado em si mesmo, tem pouco poder explicativo. Mesmo com seu viés diacrônico, a história das formas literárias que não saia do próprio plano delas não deixa de ser uma simples variante do estudo a-histórico das formas, o que tampouco se remedeia com referências genéricas a contextos culturais de diferentes períodos. Cf. SCHWARZ, R. Um mestre na periferia do capitalismo. In: . Seqüências Brasileiras. São

Paulo: Companhia das Letras, 1999. p. 222. (Entrevista).

22 ANDRADE, Mário de. Memórias de um sargento de milícias. In: Aspectos da literatura brasileira. 5. ed. São Paulo: Martins, 1974. p. 135.

23 MSM, p. 319.

24 Como se sabe, a vigência do favor na sociedade brasileira escravista foi examinada por R. Schwarz em seus estudos sobre Machado de Assis. 
implica também algumas peculiaridades na organização da subjetividade tal como figurada nas Memórias. A propósito, cabe lembrar que Antonio Candido assinalou a falta de interiorização da lei ao notar que, nesse universo em que o remorso não existe, "a repressão moral só pode existir [...] fora das consciências"25. Também esse traço da organização subjetiva pode ganhar maior especificação histórica se o observarmos no quadro das relações rixosas e de seus fundamentos sociais.

0 caráter imediatista da inclinação geral para a discórdia já sugere, nas Memórias, uma diferença em relação ao modelo "universal" do sujeito moderno implicado no romance burguês. Sendo uma manifestação aberta dos movimentos impulsivos e por assim dizer "irracionais" que deveriam ser refreados pela tendência civilizadora, a rixa contrasta com a atitude sóbria, contida, racional e realista normalizada na sociedade burguesa, de acordo com os valores postulados pelo avanço do capitalismo e da razão calculadora. Com efeito, a individuação pressupõe a renúncia às gratificações imediatas, imaginando-se cenas no horizonte temporal, em nome da manutenção material da própria existência ${ }^{26}$. Já a atuação desenfreada dos impulsos agressivos nas relações de rixa indica que, no universo social das Memórias, não se encontra - pelo menos não com a mesma intensidade - a renúncia pulsional indispensável à constituição do princípio de realidade nos termos das sociedades avançadas. Nesse sentido, o domínio do espírito rixoso sugere uma diferença significativa em relação à subjetividade no sentido definido pela civilização burguesa - e essa peculiaridade do sujeito figurada nas Memórias tem fundamento na organização econômico-social do Brasil oitocentista ${ }^{27}$.

Como já foi dito, os relacionamentos predominantes no romance são impulsionados pelo desejo de alcançar uma espécie de supremacia sobre os outros, e isso sempre ocorre por meio do

25 CANDID0, Antonio. O discurso e a cidade. São Paulo: Duas Cidades, 1993. p. 49.

26 Ver HORKHEIMER, Max. Eclipse da razão. Rio de Janeiro: Labor, 1976 e ADORNO, Theodor W.; HORKHEIMER, M. Dialética do esclarecimento. Rio de Janeiro: Jorge Zahar, 1985. Sobre o romance realista burguês, ver MORETTI, Franco. 0 século sério. Novos Estudos CEBRAP, São Paulo, n. 65, p. 3-33, mar. 2003.

27 A historicização do conceito de sujeito a partir da perspectiva periférica é um dos resultados do estudo de SCHWARZ, R. Um mestre na periferia do capitalismo. São Paulo: Duas Cidades, 1990. Ver também FIGUEIRA, Sérvulo Augusto. Machado de Assis, Roberto Schwarz: psicanalistas brasileiros? In: . Nos bastidores da psicanálise. Rio de Janeiro: Imago, 1991. p. 181-

186. Para um desenvolvimento do tema, ver AB'SÁBER, Tales. Dois mestres: crítica e psicanálise em Machado de Assis e Roberto Schwarz. In: CEVASCO, Maria Elisa; OHATA, Milton (Org.). Um critico na periferia do capitalismo: a obra de Roberto Schwarz. São Paulo: Companhia das Letras, no prelo. 
rebaixamento do rival. Não se trata tanto de uma competição em que o êxito é medido a partir de um objetivo comum, isto é, em que o triunfo depende da racionalidade definida pela relação entre as ações e a finalidade almejada. Nas disputas vigentes nas Memórias, o objeto disputado parece menos importante do que o dano moral infligido ao oponente, de tal modo que a satisfação não decorre tanto da eficácia em alcançar o objetivo, mas sim da capacidade de humilhar o adversário.

Acontece que o sentimento de superioridade assim obtido assenta-se em bases instáveis e precárias, pois está restrito à circunstância casual em que um motivo qualquer dá ocasião para a discórdia. Justamente por envolver motivos aparentemente insignificantes, o triunfo em uma rixa é sempre acompanhado de uma espécie de compensação imaginária, já que a supremacia alcançada nessas desavenças é um fato por assim dizer mais ilusório do que real. Em contraste, o poder efetivo é aquele fundado materialmente na propriedade, que, esta sim, fornece bases sólidas para o sentimento de superioridade da elite, o qual se manifesta como desrespeito, arbítrio e desmando.

A maior parte dos personagens das Memórias pertence à camada intermediária de homens livres pobres, isto é, pessoas que não eram escravos nem proprietários e oscilavam entre os expedientes da astúcia e algum tipo de relação de dependência com um poderoso. Como se sabe, a situação desses homens livres pobres era uma das inúmeras conseqüências da organização econômica (de matriz colonial) assentada sobre o escravismo. No Brasil oitocentista, o predomínio do trabalho escravo, promovido pelos interesses econômicos da classe proprietária, confinava os homens livres pobres a uma espécie de beco-sem-saída, pois os bens materiais tinham forma mercantil, mas o mercado de trabalho livre era pouco desenvolvido. Nessas condições, os homens livres pobres só encontravam maiores chances de obter os meios de sobrevivência através de mecanismos específicos, diferentes do trabalho assalariado, já que não encontravam lugar na esfera da produção, ocupada pelo trabalho escravo; daí a vigência do favor e da malandragem - o que tinha conseqüências inclusive no âmbito dos homens livres com ofícios e ocupações regulares ${ }^{28}$. Assim, pode-se dizer que, ao focalizar a camada de homens livres pobres colocando no centro da narrativa o jogo de "empenhos e cartuchos" e os expedientes ma-

28 Ver CANDID0, Antonio. Dialética da malandragem. Revista do Instituto de Estudos Brasileiros, São Paulo, n. 8, p. 67-89, 1970 e SCHWARZ, R. Ao vencedor as batatas. 2. ed. São Paulo: Duas Cidades. 1981; SCHWARZ, R. Um mestre na periferia do capitalismo. São Paulo: Duas Cidades, 1990; SCHWARZ, R. A viravolta machadiana. Novos Estudos CEBRAP, São Paulo, n. 69, p. 15-34, jul. 2004. 
landros, o romance de Manuel Antônio elabora aspectos específicos da matéria brasileira, em que estão implicadas as clivagens sociais. Quanto às rixas, para explicar historicamente sua função estrutural no romance cumpre notar, de início, que a sociedade escravista brasileira estabelecia distinções hierárquicas rígidas, em que a afirmação da desigualdade se tornava um imperativo para a definição das posições sociais. No Brasil oitocentista, a inserção social das pessoas dependia menos da situação objetiva do que das relações estabelecidas com algum proprietário ou outra instância de poder (como as instituições públicas). Assim, as posições sociais e a respeitabilidade não eram asseguradas apenas pelo ofício ou pelo estatuto civil; elas se definiam principalmente nas relações com os poderosos. Vale lembrar, a esse respeito, uma observação de Mary C. Karasch, segundo a qual os próprios escravos se discriminavam com base na hierarquia reinante entre seus donos ("os escravos elegantemente trajados de homens ricos e poderosos desprezavam os escravos malvestidos de donos sem poder"); além disso, "os escravos pardos relacionados a famílias nobres tinham muitas vezes uma posição social mais alta que marinheiros brancos livres" ${ }^{29}$. Isso ajuda a entender os comportamentos dos homens livres pobres que, sem meios próprios de vida e dependendo diretamente da proteção dos proprietários, com quem estabelecem relações de base afetivofamilista, têm tanto mais motivos para alimentar a exibição pública das relações e a supervalorização das aparências.

Nas Memórias, também se percebe que a relação com os poderosos cumpre papel importante. Embora Pataca seja um meirinho e portanto tenha relativo poder, isso não basta para salvá-lo da prisão quando é pego por Vidigal na casa do caboclo nigromante; para obter a liberdade, ele depende da intervenção do tenente-coronel, que por sua vez pede auxílio a um "fidalgo de valimento". Além disso, a relação com alguma instância de poder permite ao pobre a satisfação de colocar-se em posição de superioridade em relação a seus semelhantes. É o que se dá com Leonardo, que, transformado em granadeiro, aproveita-se dessa função para vingar-se do toma-largura (no episódio já mencionado), assim como não deixa de apreciar o susto que causa nos próprios familiares ao chegar à festa de batizado da irmã vestido com o uniforme de soldado ${ }^{30}$.

Mas não é apenas a identificação dos pobres com instâncias objetivas de poder que se encontra nas Memórias. No episódio

29 KARASCH, M. C. A vida dos escravos no Rio de Janeiro (1808-1850). São Paulo: Companhia das Letras, 2001. p. 118, 115.

30 MSM, p. 309. 
em que Leonardo consegue escapar da prisão no caminho para a Casa da Guarda, o confronto entre o herói e o chefe de polícia é acompanhado de perto pelos granadeiros, que observam o efeito causado pela fuga do malandro sobre o poderoso Vidigal e não deixam de sentir satisfação em ver o major desapontado. Humilhado, Vidigal desconfia que rissem dele pela cidade inteira:

0 major tinha razão: riam-se com efeito dele; e os primeiros que o faziam eram os granadeiros. Apesar de que, escravos da disciplina, empregavam os mais sinceros esforços para coadjuvá-lo; e apesar também de que revertia para eles alguma glória das façanhas do major, não puderam entretanto deixar de achar graça no que acabava de suceder, pois conheciam a presunção do Vidigal, e repararam na cara desapontada com que ele havia ficado. ${ }^{31}$

Geralmente recrutados à força, colocados no posto mais baixo da hierarquia militar e obrigados a obedecer ao comando de um major autoritário, os granadeiros que compõem o corpo policial não parecem ocupar uma posição particularmente privilegiada ("ser soldado era naquele tempo, e ainda hoje talvez, a pior coisa que podia suceder a um homem"32). No entanto, os soldados conseguem transformar a desvantagem do recrutamento em uma espécie de vantagem: submetem-se às ordens do chefe e com isso participam das glórias do major, num instante de identificação que se sobrepõe à divergência de interesses. A identificação com o poder lhes permite compensar a situação de inferioridade (na hierarquia militar) colocando-se em posição superior às pessoas comuns ao atuarem como instrumentos das arbitrariedades de Vidigal. Ao mesmo tempo, o fracasso do comandante não é motivo de vexame para os granadeiros, ainda que eles próprios também tenham sido logrados por Leonardo; pelo contrário, os soldados se comprazem com a desmoralização de Vidigal e passam a rir dele, identificando-se, desta vez, com o malandro que enganara o major.

Aqui encontramos, por assim dizer, a compensação imaginária em estado puro, pois, se na identificação com o poderoso ainda há um lastro objetivo no vínculo que os soldados têm com a instituição policial, no caso da ridicularização do major os granadeiros identificam-se com Leonardo apenas porque acontece de ele triunfar no confronto. A simples posição de superioridade circunstancial, alcançada pelo herói com a fuga, é suficiente para que os outros que observam a cena também zombem do major para se sentirem superiores. Assim, o movimento dos granadeiros é marcado por 
oscilações: empregam "sinceros esforços" para fazerem jus à glória emprestada e riem da presunção frustrada do major para compensar imaginariamente a posição de inferioridade a que não escapam na prática objetiva. Essa segunda atitude, em que a mera ridicularização dá acesso à superioridade momentânea, explicita o funcionamento das compensações imaginárias que acompanham as rixas.

Em suma, a relação com um proprietário - ou, no caso, com a polícia - permite aos personagens tirarem vantagens pessoais, pegando carona no poder do protetor, um pouco à maneira do criado de Brás Cubas, que se exibe na janela do palacete de seu patrão para "mostrar que não é criado de qualquer"33. Mas, quando esse tipo de relação com o poder não está ao alcance do pobre, apenas os motivos ocasionais propiciam a obtenção de um sentimento de superioridade parecido, embora menos apoiado em bases objetivas (o que não quer dizer que não tenha nenhum fundamento real). No universo das Memórias, os personagens, na maior parte, não mantêm relações duradouras com protetores poderosos - só no final Leonardo obtém o auxílio direto de D. Maria e do major Vidigal - e, por isso, lançam mão dos expedientes da malandragem, estabelecendo conflitos rixosos em busca do prestígio que não alcançam pela via do favor.

De certo modo, na falta de proteção de um poderoso, a rixa apresenta-se para os pobres como o único lugar em que é possível afirmar uma supremacia (um pouco na realidade e muito na imaginação), em vista da obtenção do sentimento de superioridade e de certo prestígio em relação aos demais. Também a conquista de prestígio nas situações circunstanciais da existência cotidiana tem implicações materiais, como o comprova o problema da inserção social no país escravista. Com poucas chances de integrar-se ao reduzido mercado de trabalho livre, o homem livre pobre não encontra meios de existência autônoma e, por isso, fica condenado a uma posição subalterna, mais ou menos inescapável. Confinado a essa situação de impotência, só resta a ele a onipotência da imaginação ${ }^{34}$, que, no entanto, por vezes lhe propicia certos benefícios pessoais no interior do sistema de desigualdades existente. As desavenças baseadas em motivos quaisquer são relacionamentos cotidianos que fornecem a possibilidade de alcançar uma superioridade

33 ASSIS, Machado de. Memórias póstumas de Brás Cubas. Rio de Janeiro: Garnier, 1988. p. 217. Ver a notável análise do episódio feita por SCHWARZ, R. Ao vencedor as batatas. 2. ed. São Paulo: Duas Cidades. 1981. p. 137.

34 Adapto aqui uma formulação, referente a outro contexto, de KEHL, Maria Rita. Trauma e ironia. 2005. Disponível em: <http://www.estadosgerais.org/ encontro/IV/PT/trabalhos/Maria_Rita_Kehl.pdf>. Acesso em: ago. 2006. 
por meio da compensação imaginária. Assim, nas Memórias proliferam as rixas entre pares, que acabam se sobrepondo ao antagonismo de classes.

Numa sociedade rigidamente hierarquizada e de pouca mobilidade, as desigualdades se reproduzem em todos os níveis, de tal modo que os relacionamentos sempre acabam repondo as marcas visíveis de diferenças hierárquicas (incluindo as imaginárias), mesmo entre aqueles que ocupam posição social equivalente. Tal como ocorre nas relações entre os poderosos e seus dependentes, em que o proprietário impõe seu arbítrio à vontade do pobre, nos relacionamentos rixosos os pobres lutam entre si, a propósito de qualquer motivo, buscando rebaixar o oponente e alcançar uma supremacia compensatória. A própria noção de igualdade parece não ter pregnância no universo dos homens livres figurado nas Memórias ${ }^{35}$.

Desse modo, no entanto, a multiplicação das rixas entre os pobres apenas reafirma as distinções e o desrespeito pelos demais, já que as vantagens alcançadas nesses conflitos pressupõem a manutenção das iniqüidades, e não a sua dissolução. Nesse sentido, o eventual triunfo (pessoal) do pobre não deixa de ser também o seu fracasso (no plano coletivo), pois a luta pela sobrevivência acaba por contribuir para a reprodução da ordem social que o oprime. Assim, a rixa revela na malandragem a sua dimensão sombria.

Finalmente, pode-se dizer que a lógica das rixas, ao mesmo tempo em que cumpre função estrutural nas Memórias, não deixa de corresponder também à lógica dos conflitos vigentes na realidade social do tempo de Manuel Antônio de Almeida, envolvendo escravos, libertos e homens livres na disputa por trabalho. É certo que, no início do romance, o antagonismo básico sugerido pelas posições sociais parece fundar-se no embate entre a vida solta dos pobres e a força repressora do Major, que atua como um delegado da classe proprietária. Contudo, os conflitos ao longo da narrativa não se articulam somente em torno da divergência de interesses entre as classes; ao contrário, predominam antes as desavenças e rixas entre os próprios pobres. Nesse sentido, vale a pena lembrar uma observação de Carlos Eugênio Líbano Soares, que estudou práticas de rebeldia escrava; segundo ele, na relação de prisões efetuadas pela polícia entre 1810 e 1821, a maior parte de ocorrências de capoeira não se dava em rusgas entre escravos e policiais, como se poderia talvez esperar, mas sim em conflitos entre os

35 A ausência da noção de igualdade entre os homens livres no Brasil escravista foi assinalada por SCHWARZ, R. A poesia envenenada de D. Casmurro. In:

Duas Meninas. São Paulo: Companhia das Letras, 1997. p. 21; e SCHWARZ, R. A viravolta machadiana. Novos Estudos CEBRAP, São Paulo, n. 69, p. 22, jul. 2004. 
próprios negros, fossem escravos, forros ou livres ${ }^{36}$. A historiografia registra também que, desde o início do século XIX, homens brancos pobres protestavam contra o treinamento de escravos em atividades especializadas. Mestres artesãos que dispunham de alguns recursos preferiam comprar escravos e treiná-los no ofício a empregar aprendizes livres. Do mesmo modo, muitos senhores colocavam seus escravos no aprendizado de um ofício, o que aumentava o valor do escravo e possibilitava maiores ganhos para seu proprietário. Essa circunstância fazia com que muitos homens brancos livres não conseguissem mais competir com os escravos de ganho na disputa por trabalho ${ }^{37}$.

Segundo Luiz Felipe de Alencastro, a partir do final da década de 1840 foi se tornando cada vez mais visível a presença maciça de homens brancos (sobretudo ilhéus) disputando trabalho com escravos de ganho nas ruas do Rio de Janeiro. Essa situação se acentuou depois da cessação do tráfico de escravos em 1850, mas já era uma realidade pelo menos desde meados da década de 1830, quando parte da frota negreira passou a ser utilizada para o transporte dos chamados "engajados" das ilhas portuguesas. Assim, no plano da vida cotidiana, por volta de 1850,

a opinião brasileira começava a captar uma realidade social cujos termos eram até então antinômicos: a existência de europeus pobres, rebaixados ao nível dos escravos, exercendo atividades e personificando formas de decadência social que pareciam ser o apanágio de negros e mestiços. ${ }^{38}$

Acresce que na mesma época se registrava um aumento significativo da população imigrante pobre nos informes

36 Ver SOARES, Carlos. E. L. A capoeira escrava e outras tradições rebeldes no Rio de Janeiro. Campinas: Ed. Unicamp, 2001. p. 85. Acrescente-se que um padrão rixoso semelhante ainda se verificava entre os trabalhadores assalariados no Rio de Janeiro do início do século XX, num momento histórico em que estava em curso a redefinição das relações de trabalho no Brasil - o que parece sugerir a persistência de condições materiais adversas que fazem prosperar as rixas urbanas. Segundo Sidney Chalhoub, nos processos criminais dessa época são raros os conflitos diretos entre patrão e empregado; na maior parte, os conflitos com desenlace violento envolvem os próprios empregados ou, ainda, empregados e desempregados. Ver CHALOUB, Sidney. Trabalho, lar e botequim: o cotidiano dos trabalhadores no Rio de Janeiro da Belle Époque. São Paulo: Brasiliense, 1986.

37 Ver KARASCH, M. C. A vida dos escravos no Rio de Janeiro (1808-1850). São Paulo: Companhia das Letras, 2001. p. 276; e ALGRANTI, Leila M. O feitor ausente: estudo sobre a escravidão urbana no Rio de Janeiro. Petrópolis: Vozes, 1988. p. 91.

38 ALENCASTRO, L. F. de. Proletários e escravos: imigrantes portugueses e cativos africanos no Rio de Janeiro, 1850-1872. Novos Estudos CEBRAP, São Paulo, n. 21, p. 50, jul. 1988. 
policiais ${ }^{39}$. Ou seja, no momento histórico em que ocorre um acirramento na disputa por trabalho envolvendo imigrantes pobres e escravos de ganho, verifica-se também uma ampliação na quantidade de rusgas urbanas com participação de imigrantes brancos. Isso parece indicar que a violência cotidiana nas ruas no Rio de Janeiro do tempo de Manuel Antônio de Almeida ligava-se, em grande medida, a uma espécie de "guerra civil do trabalho" 40 . Nesse sentido, talvez se possa dizer que o problema central da disputa por trabalho nas condições da sociedade escravista explicita o fundamento material das disputas entre homens livres pobres pelos meios de sobrevivência.

Sem vincular-se diretamente à questão do trabalho, o espírito rixoso figurado nas Memórias apreende um dos efeitos da lógica profunda da sociedade brasileira oitocentista, apresentando, no plano da elaboração ficcional, uma estrutura de rixas que, automatizada, parece funcionar por si mesma, em uma espécie de motocontínuo. Resultado da organização econômico-social, a proliferação de rixas acaba servindo também à reprodução das clivagens sociais, de que decorre a situação funesta dos homens livres pobres.

Assim, cumpre sublinhar que os relacionamentos violentos figurados nas Memórias não indicam uma simples oposição entre os impulsos da "natureza humana" e a tendência repressiva da civilização. 0 ponto de vista implicado no romance se distancia da visão conservadora segundo a qual a vida dos pobres seria o reduto da desordem e da anticivilização (devendo por isso ser controlada por uma polícia vigilante). A inclinação geral para a rixa apresentada nas Memórias mostra estar profundamente enraizada na lógica da sociedade escravista, cujas fraturas e desigualdades se reproduzem em articulação com o processo mais amplo, ele mesmo desigual, do desenvolvimento do capitalismo. Não se trata, portanto, de uma inclinação "natural" dos pobres que, abandonados a si mesmos, entregam-se aos impulsos violentos, mas sim de um padrão de comportamento socialmente mediado - e em última instância determinado pela evolução moderna da economia. Dando configuração ao espírito rixoso, o romance de Manuel Antônio de Almeida apreende as peculiaridades da sociedade periférica, resultantes da dinâmica contraditória da própria civilização, cujo fundamento incivil, tanto na periferia quanto no centro, revela o núcleo de violência próprio aos movimentos de expansão do capitalismo.

Recebido em: Nov. 2006 Aprovado em: Jan. 2007

39 Cf. SOARES, Carlos. E. L. A capoeira escrava e outras tradições rebeldes no Rio de Janeiro. Campinas: Ed. Unicamp, 2001. p. 513.

40 A expressão é de Iná Camargo Costa. 